\title{
Efficient nitrogen removal by simultaneous photoelectrocatalytic oxidation and electrochemically active biofilm denitrification
}

\author{
Qi Wang, Jianjia Xu, Yaohua Ge, Yi Zhang, Huajun Feng, Yanqing Cong* \\ School of Environmental Science and Engineering, Zhejiang Gongshang University,
} Hangzhou 310012, China

\begin{abstract}
A novel nitrogen removal strategy, the combined photoelectrocatalytic oxidation and autotrophic biofilm denitrification, was developed to achieve simultaneous $\mathrm{NH}_{4}{ }^{+}-\mathrm{N}$ oxidation and $\mathrm{NO}_{3}{ }^{-} \mathrm{N}$ reduction in a single reactor. $\mathrm{AgI} / \mathrm{TiO}{ }_{2}-\mathrm{NTs}$ and autotrophic denitrifying biofilm were used as anode and cathode, respectively. $\mathrm{NH}_{4}{ }^{+}-\mathrm{N}$ oxidation efficiency was enhanced by 3 times after the introduction of visible light. Moreover, $\mathrm{NO}_{3}{ }^{-}-\mathrm{N}$ and $\mathrm{NO}_{2}{ }^{-}-\mathrm{N}$ generated in the process of $\mathrm{NH}_{4}{ }^{+}-\mathrm{N}$ oxidation could be further removed by biocathode. Applied voltage and $\mathrm{pH}$ have significant effects on nitrogen removal. The $\mathrm{NO}_{3}{ }^{-}-\mathrm{N}$ and $\mathrm{NH}_{4}{ }^{+}-\mathrm{N}$ removal efficiencies gradually increased from $27.2 \%$ to $74.3 \%$ and $60.0 \%$ to $83.1 \%$, respectively, when the voltage increased from $1.0 \mathrm{~V}$ to $3.0 \mathrm{~V}$. Neutral or slightly alkaline condition was favorable on account of the autotrophic denitrifying biofilm. The optimum TN $\left(\mathrm{TN}=\mathrm{NH}_{4}{ }^{+}-\mathrm{N}+\right.$ $\mathrm{NO}_{3}{ }^{-} \mathrm{N}+\mathrm{NO}_{2}{ }^{-}-\mathrm{N}$ ) removal efficiency was up to $89.6 \%$ at $\mathrm{pH} 8$ with $3.0 \mathrm{~V}$ voltage.
\end{abstract}

\footnotetext{
* To whom correspondence should be addressed. E-mail: yqcong@ hotmail.com. Phone: (+86-571)-28008211. Fax: (+86-571)-28008215. 
Keywords: photoelectrocatalytic oxidation; Autotrophic denitrification biofilm; Nitrogen removal; Ammonium; Nitrate 


\section{Introduction}

Wastewater discharge containing excessive nitrogenous pollutants and artificial fixed nitrogen have drastically altered the global nitrogen cycle, leading to serious impacts on environment and human health. Aqueous ammonium $\left(\mathrm{NH}_{4}{ }^{+}-\mathrm{N}\right)$, one of the major nitrogen-containing pollutants, was recognized as a potential source of eutrophication. Nitrate $\left(\mathrm{NO}_{3}{ }^{-} \mathrm{N}\right)$, another type of nitrogen, was known to cause methemoglobinemia, "blue baby" syndrome [1], and other behavioral problems [2]. In many regions, the concentration of $\mathrm{NO}_{3}{ }^{-} \mathrm{N}$ in water is much higher than the guideline range ( $<10 \mathrm{mg} \mathrm{N} / \mathrm{L}$ ) proposed by World Health Organization for human consumption [3]. Therefore, it is crucial to develop technologies for the highly effective removal of nitrogen.

Biological technology is a traditional treatment method for nitrogen removal, which needs to carry out nitrification and denitrification in two separate reactors. In nitrification reactor, $\mathrm{NH}_{4}{ }^{+}-\mathrm{N}$ is converted into $\mathrm{NO}_{3}{ }^{-} \mathrm{N}$ and $\mathrm{NO}_{2}{ }^{-} \mathrm{N}$ in aerobic conditions. In denitrification reactor, $\mathrm{NO}_{3}{ }^{-} \mathrm{N}$ and $\mathrm{NO}_{2}{ }^{-}-\mathrm{N}$ are converted into $\mathrm{N}_{2}$ in anaerobic conditions [4]. Not only different concentrations of dissolved oxygen should be provided to nitrification and denitrification respectively, but also extra organic carbon required to denitrification may cause secondary pollution [5]. Separate aerobic and anoxic reactors, and strict control of reaction condition increase the treatment costs and operating complexity.

Recently, bioelectrochemical technology has attracted considerable attentions for nitrogen removal [6,7]. Through proper acclimation, electrochemically active 
autotrophic denitrifying bacteria immobilized on the cathode can utilize the electrons or hydrogen gas generated on the cathode as an electron donor to convert $\mathrm{NO}_{3}{ }^{-}-\mathrm{N}$ into harmless $\mathrm{N}_{2}[8,9]$. In this process, no extra organic carbon sources need to be added as electron donors. Therefore, the formation of secondary pollution can be avoided in bioelectrochemical treatment.

On the other hand, photocatalytic technology is appealing as a promising method for wastewater treatment since the photocatalysts can utilize solar energy to generate electrons $\left(e^{-}\right)$and holes $\left(h^{+}\right)$to enable redox reactions with aqueous contaminants [10]. Some studies reported that either $\mathrm{NH}_{4}{ }^{+}-\mathrm{N}$ or $\mathrm{NO}_{3}{ }^{-} \mathrm{N}$ can be removed from wastewater by $\mathrm{TiO}_{2}$-based photocatalysis through oxidative or reductive pathways, respectively [11-16]. However, the reported $\mathrm{NH}_{4}{ }^{+}-\mathrm{N}$ or $\mathrm{NO}_{3}{ }^{-}-\mathrm{N}$ removal needs to be carried out under UV light irradiation, which only accounts for approximately $4 \%$ of solar energy. Therefore, it is of crucial importance to develop novel system which can utilize abundant visible light accounting for approximately $44 \%$ of solar radiation. The well-known photosensitive but unstable $\operatorname{AgX}(\mathrm{X}: \mathrm{Br}, \mathrm{I})$ were widely applied in photographic films. Interestingly, when $\mathrm{AgX}$ was loaded onto the surface of a semiconductor, such as $\mathrm{TiO}_{2}$, the decomposition of $\mathrm{AgX}$ was drastically inhibited since the photogenerated electrons can be ultimately transferred to $\mathrm{O}_{2}$ rather than $\mathrm{Ag}^{+}$. In this way, the high visible-light-responsive performance of $\mathrm{AgX}$ can be utilized. Recently, a series of organic pollutants were reported to be efficiently degraded on $\mathrm{AgX} / \mathrm{TiO}_{2}$ under visible light irradiation [17-19]. Since the valence band (VB) edge of AgI (2.22 V vs. NHE at $\mathrm{pH} 7)[20,21]$ is more positive than the standard redox 
potential of $\mathrm{NH}_{4}^{+}\left(\mathrm{E}_{\mathrm{NO} 3-/ \mathrm{NH} 4+}=0.363 \mathrm{~V}, \mathrm{E}_{\mathrm{NO} 2-/ \mathrm{NH} 4+}=0.343 \mathrm{~V}, \mathrm{E}_{\mathrm{N} 2 / \mathrm{NH} 4+}=-0.276 \mathrm{~V}\right)$ [22], it is thermodynamically feasible that $\mathrm{NH}_{4}{ }^{+}$can be oxidatively degraded by photogenerated $h^{+}$on AgI. Besides, it is generally accepted that more efficient separation of photogenerated electron-hole pairs can be achieved in photoelectrocatalytic process by applied bias voltage than single photocatalytic one. Thus, the photogenerated holes of $\mathrm{AgX} / \mathrm{TiO}_{2}$ can be more efficiently utilized in photoelectrocatalytic reactions.

For the reduction of $\mathrm{NO}_{3}^{-}-\mathrm{N}$, hole scavengers were always added in single photocatalytic procedure, which may cause secondary pollution and greatly affected the final product $[23,24]$. Since bioelectrochemical technology was already proved to have advantages in the aspect of avoiding secondary pollution and enhancing $\mathrm{NO}_{3}{ }^{-} \mathrm{N}$ reduction, the ingenious combination of visible light photoelectrocatalytic oxidation and bioelectrochemical reduction seems to be a better choice for efficient and clean nitrogen removal within the scope of our knowledge.

In this work, a novel nitrogen removal strategy, the combined photoelectrocatalytic oxidation and autotrophic biofilm denitrification, was developed to achieve simultaneous $\mathrm{NH}_{4}{ }^{+}-\mathrm{N}$ oxidation and $\mathrm{NO}_{3}{ }^{-} \mathrm{N}$ reduction in a single reactor. Herein, a visible-light-active $\mathrm{AgI} / \mathrm{TiO}_{2}$ nanotubes (NTs) was chosen as anode for $\mathrm{NH}_{4}{ }^{+}-\mathrm{N}$ removal by photoelectrocatalytic oxidization under visible light irradiation. The electrochemically active autotrophic denitrifying biofilm were acclimated as cathode for $\mathrm{NO}_{3}{ }^{-} \mathrm{N}$ reduction. Intriguingly, different from previously reported photocatalytic oxidation or autotrophic denitrification in separate aerobic and anoxic 
reactors, this system can achieve nitrogen removal from $\mathrm{NH}_{4}{ }^{+}-\mathrm{N}$ and $\mathrm{NO}_{3}{ }^{-}-\mathrm{N}$ mixed $\mathrm{N}$-sources wastewater simultaneously in a single reactor. The results provide a low-cost and energy-clean treatment process for efficient nitrogen removal in the field of nitrogenous pollutants elimination.

\section{Methods}

\subsection{Preparation of $\mathrm{AgI} / \mathrm{TiO}_{2}-\mathrm{NT}$ s photoanode}

$\mathrm{AgI} / \mathrm{TiO}_{2}-\mathrm{NTs}$ photoanode was prepared by anodic oxidation [25] and dissolution-precipitation method. Firstly, $\mathrm{TiO}_{2}-\mathrm{NTs}$ were formed on the titanium surface by electrochemical anodization. Prior to anodization, a Ti sheet $(90 \mathrm{~mm} \times 25$ $\mathrm{mm} \times 0.35 \mathrm{~mm}, 99.5 \%$ purity) was repeatedly polished with different abrasive sandpapers to a mirror-like finish and ultrasonically cleaned in acetone, ethanol and deionized water for $15 \mathrm{~min}$, respectively. The cleaned $\mathrm{Ti}$ sheet was anodized in an electrolyte $\left(0.5 \mathrm{wt} \% \mathrm{NaF}\right.$ and $\left.0.5 \mathrm{~mol} / \mathrm{L} \mathrm{Na}_{2} \mathrm{SO}_{4}\right)$ at $20 \mathrm{~V}$ for $5 \mathrm{~h}$ in a two-electrode configuration with a same-sized copper sheet cathode. After anodization, the $\mathrm{TiO}_{2}$-NTs electrode was washed with deionized water and dried in air. Secondly, $\mathrm{AgI} / \mathrm{TiO}_{2}-\mathrm{NTs}$ electrode was obtained via the following dissolution-precipitation procedure. Namely, the as-formed $\mathrm{TiO}_{2}$-NTs electrode was dipped in KI solution $\left(1 \times 10^{-3} \mathrm{~mol} / \mathrm{L}\right)$ and $\mathrm{AgNO}_{3}$ solution $\left(1 \times 10^{-3} \mathrm{~mol} / \mathrm{L}, \mathrm{pH}=11\right)$ for $2 \mathrm{~h}$, sequentially. Finally, the dipped sample was calcined at $350^{\circ} \mathrm{C}$ for $2 \mathrm{~h}$ to obtain $\mathrm{AgI} / \mathrm{TiO}_{2}-\mathrm{NTs}_{\mathrm{s}}$ electrode (See digital photo in Fig. S1A). 


\subsection{Preparation of autotrophic denitrifying biofilm cathode}

The autotrophic denitrifying biofilm cathode was prepared according to our previous report [7]. First, autotrophic denitrifying bacteria originated from Qige wastewater treatment plant (Hangzhou, China) were incubated in an anoxic bio-electrochemical reactor (BER) with two graphite sheets $(120 \mathrm{~mm} \times 25 \mathrm{~mm} \times 4 \mathrm{~mm}$, $90 \mathrm{~mm}$ effective length) as anode and cathode, respectively. A DC voltage was applied on the electrodes and gradually increased from 0 to $3.0 \mathrm{~V}$ to acclimatize the bacteria. The electrochemically active denitrifying bacteria were selectively enriched on graphite cathode. The BER was filled with $150 \mathrm{~mL}$ growth medium. $1 \mathrm{~L}$ growth medium contained the following components [26]: $0.3 \mathrm{~g} \mathrm{KH}_{2} \mathrm{PO}_{4}, 0.4 \mathrm{~g} \mathrm{Na}_{2} \mathrm{HPO}_{4}, 0.5$ $\mathrm{g} \mathrm{NaCl}, 3.0 \mathrm{~g} \mathrm{NaHCO}_{3}, 0.1 \mathrm{~g} \mathrm{MgSO}_{4}, 0.01 \mathrm{~g} \mathrm{CaCl}_{2}, 0.3 \mathrm{~g} \mathrm{KNO}_{3}$ and $1 \mathrm{~mL}$ trace metal solution $\left(70 \mathrm{mg} / \mathrm{L} \mathrm{ZnSO} \cdot \cdot 7 \mathrm{H}_{2} \mathrm{O}, 30 \mathrm{mg} / \mathrm{L} \mathrm{Na}_{2} \mathrm{MO}_{4} \cdot 2 \mathrm{H}_{2} \mathrm{O}, 600 \mathrm{mg} / \mathrm{L} \mathrm{CoCl}{ }_{2} \cdot 6 \mathrm{H}_{2} \mathrm{O}, 30\right.$ $\mathrm{mg} / \mathrm{L} \mathrm{MnCl} l_{2} \cdot 4 \mathrm{H}_{2} \mathrm{O}, 10 \mathrm{mg} / \mathrm{L} \mathrm{CuCl}{ }_{2} \cdot \mathrm{H}_{2} \mathrm{O}, 300 \mathrm{mg} / \mathrm{L} \mathrm{H}_{3} \mathrm{BO}_{3}, 20 \mathrm{mg} / \mathrm{L} \mathrm{NiCl}_{2} \cdot 6 \mathrm{H}_{2} \mathrm{O}$ and $1000 \mathrm{mg} / \mathrm{L}$ EDTA). The $\mathrm{pH}$ of growth medium was around 7.0. Hydraulic residence time was $24 \mathrm{~h}$. The medium was boiled for $30 \mathrm{~min}$ to get rid of the dissolved oxygen (DO $<0.5 \mathrm{mg} / \mathrm{L}$ ) and cooled before being added to the BER. After 1 2 months, the autotrophic denitrification biofilm (2 3 mm thick) with good electrochemical activity was formed on the surface of cathode (See digital photo in Fig. S1B).

\subsection{Reactor start-up}

Fig. 1 showed the detailed schematic of the reactor used in this study. The reactor 
was a hermetical cube which was made of perspex $(120 \mathrm{~mm} \times 55 \mathrm{~mm} \times 55 \mathrm{~mm})$ with an open gas vent for gas-out and an influent/effluent vent on the top and a couple of electrodes $(120 \mathrm{~mm} \times 25 \mathrm{~mm} \times 4 \mathrm{~mm}, 90 \mathrm{~mm}$ effective length). To increase the electrical conductivity, $\mathrm{AgI} / \mathrm{TiO}_{2}-\mathrm{NTs}$ photoanode was stuck on a graphite sheet by graphite conducting resin (DY-50, Xilite adhesive Co., LTD, China). The structures of $\mathrm{AgI} / \mathrm{TiO}_{2}-\mathrm{NTs}$ electrodes mentioned hereinafter were all suchlike. The cathode was autotrophic denitrifying biofilm electrode or graphite electrode (control group). The two electrodes were connected to a DC power supply (WYL-302s, Silin Electronic Instrument Co., LTD, China) and the distance between the electrodes was $2 \mathrm{~cm}$. The light was supplied by a $300 \mathrm{~W}$ xenon lamp (LanSheng electronics Co., LTD, China) placed at $10 \mathrm{~cm}$ distance from the $\mathrm{AgI} / \mathrm{TiO}_{2}-\mathrm{NTs}$ electrode. A $420 \mathrm{~nm}$ optical filter was installed on the output of the lamp to ensure that the light was completely visible light, which was harmless to biofilm. Artificial wastewater was boiled to ensure an anoxic condition in the reactor. The components of the artificial wastewater was the same as the growth medium except the components of $\mathrm{NH}_{4}{ }^{+}-\mathrm{N}$ and $\mathrm{NO}_{3}{ }^{-}-\mathrm{N}$ which were changed according to different studies. The net liquid volume was $150 \mathrm{~mL}$. The study was operated at room temperature under constant magnetic stirring.

\subsection{Batch experiment}

After successful start-up, the performances of nitrogen removal from $\mathrm{NH}_{4}{ }^{+}-\mathrm{N}$ and $\mathrm{NO}_{3}{ }^{-} \mathrm{N}$ mixed $\mathrm{N}$-sources wastewater were investigated in different conditions by separate batch experiments. Liquid samples were taken every $1 \mathrm{~h}$ and the 
concentrations of $\mathrm{NH}_{4}^{-}-\mathrm{N}, \mathrm{NO}_{2}^{-}-\mathrm{N}$ and $\mathrm{NO}_{3}{ }^{-}-\mathrm{N}$ were measured according to standard methods for the examination of water and wastewater [27]. The effects of single photoelectrocatalysis on $\mathrm{NH}_{4}{ }^{-} \mathrm{N}$ removal and combined photoelectrocatalysis -autotrophic denitrifying biofilm on nitrogen removal were examined at different applied voltages under visible light irradiation. In addition, the nitrogen removal without visible light irradiation or applied voltage was also studied in the same reactor to further identify the role of electrocatalysis and photocatalysis, respectively. In all the above experiments, the values of $\mathrm{pH}$ were kept around 8.0. The nitrogenous concentration of simulated wastewater was $35.0 \pm 2.0 \mathrm{mg} / \mathrm{L} \mathrm{NH}_{4}{ }^{+}-\mathrm{N}$ and $20.0 \pm 2.0$ $\mathrm{mg} / \mathrm{L} \mathrm{NO}_{3}{ }^{-} \mathrm{N}$.

\subsection{Analytical methods}

The concentrations of $\mathrm{NH}_{4}{ }^{+}-\mathrm{N}, \mathrm{NO}_{3}{ }^{-}-\mathrm{N}$ and $\mathrm{NO}_{2}{ }^{-}-\mathrm{N}$ were calculated by five-point external standard calibration curves using a UV/Vis spectrophotometer (Unico UV-2102 PC). In detail, $\mathrm{NO}_{3}{ }^{-} \mathrm{N}$ concentrations were determined using corrected absorbance $\left(A_{c}=A_{220}-2 A_{275}\right)$ by monitoring the absorbance at $220 \mathrm{~nm}\left(\mathrm{~A}_{220}\right)$ and 275 $n m\left(\mathrm{~A}_{275}\right)$, respectively [7,27]. $\mathrm{NO}_{2}{ }^{-} \mathrm{N}$ concentrations were measured by sulfanilamide colorimetric method [7,27]. The corrected absorbance $\left(A_{c}=A_{540}-A_{H 2 O}\right)$ was estimated by monitoring the absorbance at $540 \mathrm{~nm}$ in the sample solution $\left(\mathrm{A}_{540}\right)$ and control water solution $\left(\mathrm{A}_{\mathrm{H} 2 \mathrm{O}}\right)$ after adding colorimetric reagents. The method for $\mathrm{NH}_{4}{ }^{+}$analysis was Nessler reagent-colorimetry [27]. $\mathrm{NH}_{4}^{+}$concentrations were estimated using corrected absorbance $\left(\mathrm{A}_{\mathrm{c}}=\mathrm{A}_{420}-\mathrm{A}_{\mathrm{H} 2 \mathrm{O}}\right)$ by monitoring the absorbance at $420 \mathrm{~nm}$ in the sample solution $\left(\mathrm{A}_{420}\right)$ and control water solution $\left(\mathrm{A}_{\mathrm{H} 2 \mathrm{O}}\right)$ after adding Nessler reagent. The dehydrogenase activity of the autotrophic denitrification biofilm was determined by measuring 2,3,5-triphenyl-tetrazoliumchloride dehydrogenase 
activity $[7,32]$. One enzyme unit was defined as the amount of enzyme producing $1 \mu \mathrm{g}$ of triphenylformazan salt per hour.

\section{Results and discussion}

\subsection{Characterization of $\mathrm{AgI} / \mathrm{TiO} \mathrm{O}_{2}$-NTs electrode}

The structure and morphology of $\mathrm{AgI} / \mathrm{TiO}_{2}-\mathrm{NTs}$ photoanode were investigated by XRD and SEM, respectively. As depicted in Fig. S2, obvious diffraction peaks of anatase $\mathrm{TiO}_{2}$ were observed, while the intensity of $\mathrm{AgI}$ was relatively very weak indicating low loading amount. In detail, $\operatorname{AgI}$ was identified as a mixture of $\beta$ and $\gamma$ phase. Moreover, $\mathrm{TiO}_{2}$-NTs were successfully fabricated via the anodization method (Fig. S3A). Almost uniform and hollow $\mathrm{TiO}_{2}$-NTs with diameter ranging from $80 \mathrm{~nm}$ to $100 \mathrm{~nm}$ could be observed. Small particles ascribing to AgI were observed to be deposited on $\mathrm{TiO}_{2}$-NTs (Fig. S3B). By EDX analysis (Fig. S3C), the atomic ratio of $\mathrm{Ag}$ to $\mathrm{Ti}$ was calculated to be $1.25 \%$, indicating that very low content of AgI was loaded on $\mathrm{TiO}_{2}$-NTs.

\section{2. $\mathrm{NH}_{4}{ }^{+}-\mathrm{N}$ removal by photoelectrocatalytic oxidation}

The role of photoelectrocatalysis in nitrogen removal was studied under the On/Off visible light irradiation. $\mathrm{AgI} / \mathrm{TiO}_{2}-\mathrm{NT}$ s electrode and graphite electrode were used as the anode and the cathode, respectively. A voltage of $3.0 \mathrm{~V}$ was applied on the two electrodes. Fig. 2a showed the effect of photoelectrocatalysis on $\mathrm{NH}_{4}{ }^{+}-\mathrm{N}$ removal. Under dark condition, the concentration of $\mathrm{NH}_{4}{ }^{+}-\mathrm{N}$ decreased from $36.9 \mathrm{mg} / \mathrm{L}$ to 28.3 
$\mathrm{mg} / \mathrm{L}$ after $12 \mathrm{~h}$, and the removal efficiency was only $23.3 \%$. However, under visible light irradiation, the concentration of $\mathrm{NH}_{4}{ }^{+}-\mathrm{N}$ decreased from $36.0 \mathrm{mg} / \mathrm{L}$ to $10.4 \mathrm{mg} / \mathrm{L}$. The removal efficiency reached $71.1 \%$. The $\mathrm{NH}_{4}{ }^{+}-\mathrm{N}$ removal efficiency under visible light irradiation was 3 times higher than that without light irradiation, indicating that photocatalysis had a significantly positive effect on $\mathrm{NH}_{4}{ }^{+}-\mathrm{N}$ removal.

To identify the variation of $\mathrm{NH}_{4}{ }^{+}-\mathrm{N}$ during the photoelectrocatalytic process, the concentrations of $\mathrm{NO}_{3}{ }^{-} \mathrm{N}$ and $\mathrm{NO}_{2}{ }^{-} \mathrm{N}$ were also determined (Fig. 2b). Under dark condition, there were no observable accumulations of $\mathrm{NO}_{3}{ }^{-}-\mathrm{N}$ and $\mathrm{NO}_{2}{ }^{-} \mathrm{N}$ after $12 \mathrm{~h}$, indicating that $\mathrm{NH}_{4}{ }^{+}-\mathrm{N}$ was not converted to $\mathrm{NO}_{3}{ }^{-}-\mathrm{N}$ and $\mathrm{NO}_{2}{ }^{-}-\mathrm{N}$. Thus, the $\mathrm{NH}_{4}{ }^{+}-\mathrm{N}$ removal efficiency of $23.3 \%$ under dark condition (see Fig. 2a) was probably due to the volatilization of $\mathrm{NH}_{4}{ }^{+}-\mathrm{N}$ into air or oxidation to $\mathrm{N}_{2}$ (represented as Loss). Under visible light irradiation, the concentrations of $\mathrm{NO}_{3}{ }^{-} \mathrm{N}$ and $\mathrm{NO}_{2}^{-}-\mathrm{N}$ after $12 \mathrm{~h}$ reaction were $14.7 \mathrm{mg} / \mathrm{L}$ and $1.0 \mathrm{mg} / \mathrm{L}$, respectively, indicating that about $43.6 \%$ of $\mathrm{NH}_{4}{ }^{+}-\mathrm{N}$ was oxidized to $\mathrm{NO}_{3}{ }^{-}-\mathrm{N}$ and $\mathrm{NO}_{2}{ }^{-}-\mathrm{N}$ by photoelectrocatalytic reaction. According to the nitrogen mass conservation, about $27.5 \%$ of $\mathrm{NH}_{4}{ }^{+}-\mathrm{N}$ was oxidized to gaseous products or volatilized to air (Loss). Others were in the wastewater in the form of $\mathrm{NH}_{4}{ }^{+}-\mathrm{N}(28.9 \%), \mathrm{NO}_{3}{ }^{-}-\mathrm{N}(40.8 \%)$ and $\mathrm{NO}_{2}{ }^{-}-\mathrm{N}$ (2.8\%) (Fig. 2c). To make clear the portion of volatilization, a blank experiment without any electric current was also performed in the dark. As shown in Fig. S4, the concentration of $\mathrm{NH}_{4}{ }^{+}-\mathrm{N}$ decreased from $35.4 \mathrm{mg} / \mathrm{L}$ to $27.8 \mathrm{mg} / \mathrm{L}$ after $12 \mathrm{~h}$ constant stirring in the dark at $0 \mathrm{~V}$ applied potential. The formation of $\mathrm{NO}_{3}{ }^{-} \mathrm{N}$ and $\mathrm{NO}_{2}{ }^{-} \mathrm{N}$ were negligible. Thus, the Loss $(21.6 \%)$ in the blank experiment can be attributed to volatilization of ammonia. 
However, under both visible light irradiation and 3.0 V applied potential, the value of Loss was about $27.5 \%$ (Fig. 2c), which is larger than blank experiment. Therefore, the oxidation of $\mathrm{NH}_{4}{ }^{+}-\mathrm{N}$ to gaseous products can not be excluded, and the word "Loss" was still used to represent volatilization of $\mathrm{NH}_{4}{ }^{+}-\mathrm{N}$ into air and oxidation to gaseous products. For convenience, the amount of $\mathrm{NH}_{4}{ }^{+}-\mathrm{N}$ removal mentioned below includes the Loss.

\subsection{Nitrogen removal by combined photoelectrocatalysis and autotrophic denitrifying}

biofilm system

In order to study the removal of $\mathrm{NO}_{3}{ }^{-} \mathrm{N}$ and $\mathrm{NO}_{2}{ }^{-} \mathrm{N}$, an electrochemically active autotrophic denitrifying biofilm electrode was used instead of graphite electrode as the cathode in the experimental group. For comparison, a graphite electrode was also used as cathode in the blank group. The anodes were both $\mathrm{AgI} / \mathrm{TiO}_{2}-\mathrm{NT}$ s electrodes. The initial $\mathrm{NH}_{4}{ }^{+}-\mathrm{N}$ and $\mathrm{NO}_{3}{ }^{-}-\mathrm{N}$ concentrations in their mixed wastewater were about $35.0 \mathrm{mg} / \mathrm{L}$ and $20.0 \mathrm{mg} / \mathrm{L}$, respectively.

Under visible light irradiation for $12 \mathrm{~h}$, the performances of nitrogen removal were shown in Fig. 3. It can be seen that the $\mathrm{NH}_{4}{ }^{+}-\mathrm{N}$ removal efficiency in the autotrophic denitrifying biofilm cathode group was a little higher than that in the graphite cathode blank group, which were both more than $70 \%$ (Fig. 3a). However, the difference of $\mathrm{NO}_{3}{ }^{-} \mathrm{N}$ concentrations between the two groups was very obvious. In the autotrophic denitrifying biofilm electrode group, the concentration of $\mathrm{NO}_{3}{ }^{-}-\mathrm{N}$ firstly increased and then decreased from about $28.4 \mathrm{mg} / \mathrm{L}$ to $11.9 \mathrm{mg} / \mathrm{L}$. The increasing $\mathrm{NO}_{3}{ }^{-} \mathrm{N}$ came 
from the photoelectrocatalytic process. The decreasing $\mathrm{NO}_{3}{ }^{-} \mathrm{N}$ concentration was due to the denitrification action of electrochemically active autotrophic denitrifying biofilm electrode. In the blank group, the concentration of $\mathrm{NO}_{3}{ }^{-} \mathrm{N}$ gradually increased to $30.4 \mathrm{mg} / \mathrm{L}$ which was higher than the initial concentration (Fig. 3b). It can be concluded that $\mathrm{NH}_{4}{ }^{+}-\mathrm{N}$ was converted to $\mathrm{NO}_{3}{ }^{-} \mathrm{N}$ by photoelectrocatalytic process under visible light irradiation, but $\mathrm{NO}_{3}{ }^{-} \mathrm{N}$ was not effectively reduced by graphite cathode. In addition, it was found based on Fig. 3c that the application of autotrophic denitrifying biofilm cathode also inhibited the formation of $\mathrm{NO}_{2}^{-}-\mathrm{N}$. Therefore, photoelectrocatalysis and autotrophic denitrifying biofilm could be applied simultaneously in a single reactor to achieve efficient nitrogen removal from $\mathrm{NH}_{4}{ }^{+}-\mathrm{N}$ and $\mathrm{NO}_{3}{ }^{-}-\mathrm{N}$ mixed $\mathrm{N}$-sources wastewater.

\subsection{Effect of different applied voltages on nitrogen removal}

Since the promotion of nitrogen removal was demonstrated with the presences of both photoelectrocatalysis and autotrophic denitrifying biofilm, four applied voltages $(1.0,2.0,3.0$ and $4.0 \mathrm{~V})$ were applied to investigate the effect of different applied voltages on nitrogen removal from $\mathrm{NH}_{4}{ }^{+}-\mathrm{N}$ and $\mathrm{NO}_{3}{ }^{-}-\mathrm{N}$ mixed $\mathrm{N}$-sources wastewater. Similarly, $\mathrm{AgI} / \mathrm{TiO}_{2}-\mathrm{NTs}$ was used as anode and autotrophic denitrifying biofilm as cathode. Fig. 4a showed that the removal efficiency of $\mathrm{NH}_{4}{ }^{+}-\mathrm{N}$ without applied voltage $(0 \mathrm{~V})$ was $36.6 \%$. When the applied voltage increased from $1.0 \mathrm{~V}$ to $3.0 \mathrm{~V}$, the removal efficiency of $\mathrm{NH}_{4}{ }^{+}-\mathrm{N}$ increased from $60.0 \%$ to $83.1 \%$. However, when the applied voltage increased to $4.0 \mathrm{~V}$, the value decreased to $76.7 \%$. These results 
indicated that the photoelectrocatalytic activity was greatly enhanced with appropriate applied voltages. Since photogenerated electrons can be driven away from holes under an applied voltage, reduced recombination rate and improved utilization ratio of holes can be thus obtained. The optimal applied potential was estimated to be $3.0 \mathrm{~V}$ in the tested range.

Fig. $4 \mathrm{~b}$ showed the denitrification efficiency and the accumulation of $\mathrm{NO}_{2}^{-}-\mathrm{N}$ under different applied voltages. When the applied voltage increased from 1.0 to $4.0 \mathrm{~V}$, the removal efficiency of $\mathrm{NO}_{3}{ }^{-} \mathrm{N}$ were $27.2 \%, 50.6 \%, 74.3 \%$ and $52.3 \%$, respectively. As a comparison, the removal efficiency of $\mathrm{NO}_{3}{ }^{-} \mathrm{N}$ in blank test without applied voltage was $8.3 \%$. Obviously, the denitrification was facilitated by an applied voltage. The accumulations of $\mathrm{NO}_{2}{ }^{-}-\mathrm{N}$ were $0.68 \mathrm{mg} / \mathrm{L}, 0.72 \mathrm{mg} / \mathrm{L}, 0.54 \mathrm{mg} / \mathrm{L}, 0.32 \mathrm{mg} / \mathrm{L}$ and $0.86 \mathrm{mg} / \mathrm{L}$ under different applied voltages $(0 \mathrm{~V}, 1.0 \mathrm{~V}, 2.0 \mathrm{~V}, 3.0 \mathrm{~V}$ and $4.0 \mathrm{~V})$, respectively. The minimum accumulation of $\mathrm{NO}_{2}{ }^{-} \mathrm{N}(0.32 \mathrm{mg} / \mathrm{L})$ was observed when the applied voltage was $3.0 \mathrm{~V}$. Thus, applied voltages could facilitate the denitrification and decrease the accumulation of $\mathrm{NO}_{2}^{-}-\mathrm{N}$. In this work, the optimal applied voltage was $3.0 \mathrm{~V}$. Continuous current is a main control factor for electrochemically active biofilm denitrification. Higher voltages are helpful to generate more hydrogen gas by electrolysis so that there are enough electron donors for denitrification. However, extravagant voltages would lead to so much hydrogen gas that the structure of the biofilm was destroyed. What is more, overmuch hydrogen gas caused "hydrogen inhibition" [28]. It was harmful to the growth and metabolism of biofilm. Therefore, it is reasonable that the removal efficiency decreased when the 
applied voltage was $4.0 \mathrm{~V}$.

Denitrification coupled to $\mathrm{NH}_{4}{ }^{+}-\mathrm{N}$ photoelectrocatalytic removal was enhanced which can be demonstrated by the TN removal with the applied voltages. Fig. 4c showed the TN removal efficiency under four applied voltages. Maximum TN removal (89.6\%) was observed at an applied voltage of $3.0 \mathrm{~V}$ in the present study.

\subsection{Effect of pH on nitrogen removal}

The performances of nitrogen removal at different $\mathrm{pH}$ values were examined in the reactors under visible light irradiation at $3.0 \mathrm{~V}$ applied voltage. $\mathrm{AgI} / \mathrm{TiO}_{2}-\mathrm{NTs}$ electrode and autotrophic denitrifying biofilm electrode were used as anode and cathode, respectively. The initial concentrations of $\mathrm{NH}_{4}{ }^{+}-\mathrm{N}$ and $\mathrm{NO}_{3}{ }^{-}-\mathrm{N}$ were about $36.0 \mathrm{mg} / \mathrm{L}$ and $20.0 \mathrm{mg} / \mathrm{L}$, respectively.

As shown in Fig. 5a, the optimal pH for denitrification was about 7.5 in this work. With an increase of $\mathrm{pH}$ value from 6.0 to 9.0 , denitrification efficiency increased in the $\mathrm{pH}$ range of $6.0 \sim 7.5$ and then decreased $(\mathrm{pH}$ 8.0 9.0). The maximum denitrification efficiency was $84.6 \%$ when the $\mathrm{pH}$ value was 7.5 . Denitrification declination was observed at higher or lower $\mathrm{pH}$ range. When the $\mathrm{pH}$ increased to 9.0 or decreased to 6.0 , the denitrification efficiencies declined significantly to $48.9 \%$ or $45.8 \%$, respectively. Besides, the $\mathrm{pH}$ value was found to play an important role in $\mathrm{NO}_{2}{ }^{-}-\mathrm{N}$ accumulation. At $\mathrm{pH} 7.5$ and 8.0, the accumulations of $\mathrm{NO}_{2}^{-}-\mathrm{N}$ were 0.37 $\mathrm{mg} / \mathrm{L}$ and $0.32 \mathrm{mg} / \mathrm{L}$, respectively, which were lower than the $\mathrm{NO}_{2}{ }^{-}-\mathrm{N}$ accumulations at other $\mathrm{pH}$ values. $\mathrm{NO}_{2}^{-}-\mathrm{N}$ accumulations were all more than $1.0 \mathrm{mg} / \mathrm{L}$ in higher or 
lower $\mathrm{pH}$ range. It was reported that the optimum $\mathrm{pH}$ for denitrification was $7.5 \sim 8.0$ $[29,30]$. And the $\mathrm{pH}$ value higher than 9.0 or lower than 6.0 would cause a significant recession or even a stop of denitrification [31]. The optimal $\mathrm{pH}$ in this work for denitrification was about 7.5 8.0 which was in accordance with the reported value.

From Fig. 5b, it can be seen that the removal efficiency of $\mathrm{NH}_{4}{ }^{+}-\mathrm{N}$ was enhanced with increasing $\mathrm{pH}$ (from 6.0 to 9.0). Since the removal of $\mathrm{NH}_{4}{ }^{+}-\mathrm{N}$ consists of two parts, including photoelectrocatalytic oxidation and volatilization, the promoting effect of $\mathrm{pH}$ on which part should be distinguished to verify the superiority of combined photoelectrocatalysis and bioelectrochemical technology in the present study.

Since $\mathrm{pH}$ value could affect the equilibrium between $\mathrm{NH}_{4}{ }^{+}$and $\mathrm{NH}_{3}$, and higher $\mathrm{pH}$ would improve the volatilization of $\mathrm{NH}_{3}$ from water, the effect of $\mathrm{pH}$ on the volatilization of $\mathrm{NH}_{4}{ }^{+}-\mathrm{N}$ into air should be considered first. As illustrated in Fig. S5, the percentage of TN "Loss" (composed of the volatilization of $\mathrm{NH}_{4}{ }^{+} \mathrm{N}$ into air, $\mathrm{NH}_{4}{ }^{+}-\mathrm{N}$ oxidation to $\mathrm{N}_{2}$, and $\mathrm{NO}_{3}{ }^{-}-\mathrm{N}$ reduction to $\mathrm{N}_{2}$ ) was significantly increased at $\mathrm{pH}>7$. For example, the value of TN "Loss" was calculated to be $25.5 \%$ and $53.4 \%$ at $\mathrm{pH} 6$ and $\mathrm{pH} 7.5$, respectively. The largest value was observed at $\mathrm{pH} 8$ (79.8\%). However, when $\mathrm{pH}$ further vincreased to 9, the value of TN "Loss" decreased slightly to $77.6 \%$. Since the volatilization of $\mathrm{NH}_{4}{ }^{+}-\mathrm{N}$ was more likely to happen at $\mathrm{pH} 9$ than $\mathrm{pH} 8$, the contribution of volatilization to TN "Loss" should not be the dominant factor.

The above conclusion can also be verified by the control experiment using graphite 
electrode as cathode for the photoelectrocatalytic oxidation of single $\mathrm{NH}_{4}{ }^{+}-\mathrm{N}$ (Fig. 2c). Also at $\mathrm{pH} 8$ and $3.0 \mathrm{~V}$ voltage, the value of Loss was $27.5 \%$ when $71.1 \% \mathrm{NH}_{4}{ }^{+}-\mathrm{N}$ was removed. Comparing with the removal of $\mathrm{NH}_{4}{ }^{+}-\mathrm{N}$ in $\mathrm{NH}_{4}{ }^{+}-\mathrm{N}$ and $\mathrm{NO}_{3}{ }^{-}-\mathrm{N}$ mixture using electrochemically active autotrophic denitrifying biofilm as cathode, the value of TN "Loss" (79.8\%) drastically increased while the change in removal efficiency of $\mathrm{NH}_{4}{ }^{+}-\mathrm{N}(83.2 \%)$ was relatively very small. Besides, it has been verified in Fig. 5a that the denitrification efficiency was much high at $\mathrm{pH} 8.0$ than $\mathrm{pH} 9.0$. Therefore, the reduction of $\mathrm{NO}_{3}^{-}-\mathrm{N}$ to $\mathrm{N}_{2}$ by electrons or hydrogen in the denitrification process may probably be the main contributor to the largest TN "Loss" at $\mathrm{pH}$ 8. Accordingly, the rapid electron-hole separation can be achieved which may meanwhile increase the oxidative removal dynamic of $\mathrm{NH}_{4}{ }^{+}-\mathrm{N}$ by the photoanode.

Considering that the denitrification process would be restricted but the $\mathrm{NH}_{4}{ }^{+} \mathrm{N}$ removal would be improved when $\mathrm{pH}$ was higher than 7.5 , the $\mathrm{TN}$ removal was measured to find out the optimum $\mathrm{pH}$ circumstance. As shown in Fig. 5c, the maximum $\mathrm{TN}$ removal efficiency was $89.6 \%$ when $\mathrm{pH}$ was 8.0 . Therefore, the favorable $\mathrm{pH}$ value was 8.0 for the whole combined process of photoelectrocatalysis and electrochemically active autotrophic denitrifying biofilm.

\subsection{The stability of the $\mathrm{AgI} / \mathrm{TiO} \mathrm{O}_{2}-\mathrm{NTS}$ anode}

In the present study, the stability of the $\mathrm{AgI} / \mathrm{TiO}_{2}-\mathrm{NTs}$ anode in long time experiments was investigated in two ways. First, cyclic runs were conducted for the removal of $\mathrm{NH}_{4}{ }^{+}-\mathrm{N}$ using $\mathrm{AgI} / \mathrm{TiO}_{2}-\mathrm{NTs}$ anode and an autotrophic denitrifying 
biofilm cathode under visible light irradiation at optimized condition. As shown in Fig. $6 a$, little change of activity was observed. Moreover, the cyclic photocurrent response of $\mathrm{AgI} / \mathrm{TiO}_{2}-\mathrm{NTs}$ anode was also tested in $0.1 \mathrm{M} \mathrm{Na}_{2} \mathrm{SO}_{4}$ solution and the results were shown in Fig. 6b. In the tested potential range from $0 \mathrm{~V}$ to $0.6 \mathrm{~V}$ ( $\mathrm{vs} \mathrm{Ag} / \mathrm{AgCl}$ ), negligible loss of photocurrent was observed after 8 repeated runs, indicating stable photoelectrocatalytic property. Overall, $\mathrm{AgI} / \mathrm{TiO}_{2}-\mathrm{NTs}$ anode exhibits good stability and cyclic performance.

\subsection{The stability of the denitrifying biofilm cathode}

In order to investigate the effect of oxidative species (photogenerated holes or free radicals) on the stability of autotrophic denitrification biofilm, dynamic study for removal of $\mathrm{NH}_{4}{ }^{+}-\mathrm{N}$ and $\mathrm{NO}_{3}{ }^{-}-\mathrm{N}$ mixture was firstly carried out under UV-A light irradiation which is much more powerful than visible light. Herein, pristine and stable $\mathrm{TiO}_{2}$-NTs with more positive valence band $(+2.7 \mathrm{~V}$ at $\mathrm{pH} 7)$ [33] was used as anode. It can be observed from Fig. S6 that the denitrification action of electrochemically active autotrophic denitrifying biofilm was greatly inhibited by UV-A light. Interestingly, although $\mathrm{TiO}_{2}$-NTs can not be excited by visible light, high activity for $\mathrm{NO}_{3}{ }^{-} \mathrm{N}$ removal can still be observed using $\mathrm{TiO}_{2}-\mathrm{NTs}$ anode and biofilm cathode under visible light irradiation. Thus, it can be inferred that UV-A light is harmful to the biolfim cathode, while visible light is harmless. Furthermore, the stability of the denitrifying biofilm cathode was also investigated when $\mathrm{AgI} / \mathrm{TiO}_{2}-\mathrm{NTs}$ was used as anode. By measuring dehydrogenase activity of the biofim during visible light 
irradiation, the stability of the denitrifying biofilm can be quantitatively assessed. As shown in Fig. 7, the dehydrogenase activity of the biofilm cathode after $12 \mathrm{~h}$ visible light irradiation was $13.0 \mu \mathrm{g} /(\mathrm{mL} \cdot \mathrm{h})$, which exhibited negligible difference to that before visible light irradiation.

\subsection{Probable nitrogen removal pathway}

For more information on the mechanism of ammonia oxidation, cyclic voltammetry $(\mathrm{CV})$ measurements were conducted with the addition of $\mathrm{NH}_{4}{ }^{+}$or $\mathrm{Ag}^{+}$ using $\mathrm{AgI} / \mathrm{TiO}_{2}-\mathrm{NTs}$ anode and $\mathrm{Pt}$ cathode, respectively. To avoid the reduction of $\mathrm{Ag}^{+}$ added or products formed from $\mathrm{NH}_{4}{ }^{+}$oxidation on cathode, the $\mathrm{CV}$ experiments were carried out in two separate cells using salt bridge as connection. The effect of $\mathrm{NH}_{4}{ }^{+}$ addition on the $\mathrm{CV}$ of $\mathrm{AgI} / \mathrm{TiO}_{2}-\mathrm{NTs}$ was shown in Fig. S7a. An oxidative peak at $0.29 \mathrm{~V}$ vs $\mathrm{Ag} / \mathrm{AgCl}\left(0.49 \mathrm{~V}\right.$ vs NHE) appeared after addition of $20 \mathrm{mg} / \mathrm{L} \mathrm{NH}_{4}{ }^{+}$. When the concentration of $\mathrm{NH}_{4}{ }^{+}$increased to $50 \mathrm{mg} / \mathrm{L}$, the peak gradually shifted to $0.27 \mathrm{~V}$ vs $\mathrm{Ag} / \mathrm{AgCl}(0.47 \mathrm{~V}$ vs NHE). To exclude the possible oxidation of $\mathrm{AgI}$ on the anode, control experiment using $\mathrm{TiO}_{2}$-NTs was also performed. As shown in Fig. S7b, similar oxidative peak with much lower intensity was still observed. Moreover, the current response increased gradually with increasing concentration of $\mathrm{NH}_{4}{ }^{+}$. Thus, the oxidative peak was ascribed to the oxidation of $\mathrm{NH}_{4}{ }^{+}$not $\mathrm{I}^{-}$in the lattice of AgI. In the same way, the effect of $\mathrm{AgNO}_{3}$ addition on the $\mathrm{CV}$ of $\mathrm{AgI} / \mathrm{TiO}_{2}-\mathrm{NTs}$ anode was also investigated and the result was shown in Fig. S7c. No signal of oxidative peaks were observed in the tested potential range, which may be probably due to high redox 
potential of $\mathrm{Ag}^{3+} / \mathrm{Ag}^{+}\left(\mathrm{E}^{0}=1.9 \mathrm{~V}\right.$ vs $\left.\mathrm{NHE}\right)$ and $\mathrm{Ag}^{3+} / \mathrm{Ag}^{2+}\left(\mathrm{E}^{0}=1.8 \mathrm{~V}\right.$ vs NHE$)$. Above all, oxidation of $\mathrm{NH}_{4}{ }^{+}$by the photogenerated holes was more easily than oxidation of $\mathrm{Ag}^{+}$or $\mathrm{I}^{-}$in $\mathrm{AgI}$ lattice.

Based on the results above, the probable nitrogen removal pathway could be represented as Fig. 8a. In the photoelectrocatalytic oxidation process, $\mathrm{AgI} / \mathrm{TiO}_{2}-\mathrm{NTs}$ anode could generate electron-hole pairs under visible light irradiation. Its conduction band edge and valence band edge fully covers the redox position of $\mathrm{NH}_{4}{ }^{+}$, indicating that photoelectrocatalytic oxidation of $\mathrm{NH}_{4}{ }^{+}-\mathrm{N}$ was thermodynamically feasible on the $\mathrm{AgI} / \mathrm{TiO}_{2}-\mathrm{NTs}$ anode (Fig. 8b). When an artificial wastewater containing $\mathrm{NH}_{4}{ }^{+}-\mathrm{N}$ and $\mathrm{NO}_{3}{ }^{-} \mathrm{N}$ flowed into the reactor, a part of $\mathrm{NH}_{4}{ }^{+}-\mathrm{N}$ was oxidized to $\mathrm{N}_{2}$ (evidenced by MS spectra in Fig. S8) by photo-generated holes on the surface $\mathrm{AgI} / \mathrm{TiO}_{2}-\mathrm{NTs}$ electrode under visible light conditions. Meanwhile, some $\mathrm{NH}_{4}{ }^{+}-\mathrm{N}$ was oxidized to $\mathrm{NO}_{2}{ }^{-} \mathrm{N}$ and $\mathrm{NO}_{3}{ }^{-} \mathrm{N}$ by holes. In this process, a small part of $\mathrm{NH}_{4}{ }^{+}-\mathrm{N}$ volatilized into air because of continuous stirring. Some researchers also reported that $\mathrm{NH}_{4}{ }^{+}-\mathrm{N}$ was oxidized by holes produced on the surface of $\mathrm{TiO}_{2}$ photocatalyst $[11,13]$ under UV light irradiation. Our work used the $\mathrm{AgI}$ sensitized $\mathrm{TiO}_{2}-\mathrm{NTs}$ which could oxidize $\mathrm{NH}_{4}{ }^{+}-\mathrm{N}$ under harmless visible light irradiation, so that the autotrophic denitrifying biofilm on the cathode would not be affected by harmful UV light.

In the denitrification process on the surface of autotrophic denitrifying biofilm cathode, $\mathrm{NO}_{2}{ }^{-}-\mathrm{N}$ and $\mathrm{NO}_{3}{ }^{-}-\mathrm{N}$ generated on anode moved to cathode, where they were reduced to $\mathrm{N}_{2}$ by autotrophic denitrifying biofilm at an applied voltage condition. Hydrogen produced on cathode served as electron donors in the process of autotrophic 
biofilm denitrification. Moreover, the constant production of $\mathrm{H}_{2}$ on the surface of cathode created an anoxic condition around autotrophic biofilm. According to experimental results using graphite electrode as cathode, it was found that $\mathrm{NO}_{2}{ }^{-}-\mathrm{N}$ and $\mathrm{NO}_{3}{ }^{-} \mathrm{N}$ could seldom be reduced by photo-generated electrons in this reaction condition. Therefore, the removal of $\mathrm{NO}_{2}^{-}-\mathrm{N}$ and $\mathrm{NO}_{3}{ }^{-} \mathrm{N}$ were attributed to autotrophic biofilm denitrification.

\section{Conclusions}

The present study provides a novel strategy for efficient nitrogen removal from $\mathrm{NH}_{4}{ }^{+}-\mathrm{N}$ and $\mathrm{NO}_{3}{ }^{-}-\mathrm{N}$ mixed $\mathrm{N}$-sources wastewater in a single reactor via simultaneous photoelectrocatalytic oxidation and autotrophic biofilm denitrification. About $27.5 \%$ $\mathrm{NH}_{4}{ }^{+}-\mathrm{N}$ was oxidized to $\mathrm{N}_{2}$ or volatilized to air, and $43.6 \% \mathrm{NH}_{4}{ }^{+}-\mathrm{N}$ was oxidized to $\mathrm{NO}_{3}{ }^{-} \mathrm{N}$ and $\mathrm{NO}_{2}^{-}-\mathrm{N}$ by photoelectrocatalytic reaction. The $\mathrm{NO}_{2}^{-}-\mathrm{N}$ and $\mathrm{NO}_{3}{ }^{-}-\mathrm{N}$ were further reduced to $\mathrm{N}_{2}$ by autotrophic denitrifying biofilm. In this way, complete nitrogen removal was achieved. Applied voltage and $\mathrm{pH}$ were critical factors affecting nitrogen removal, while the optimum values were $3.0 \mathrm{~V}$ and 8.0, respectively.

\section{Acknowledgement}

This work was financially supported by the Zhejiang Provincial Natural Science Foundation of China (LY14E080002 and LY14B070002), the National Science Foundation of China (21477114), and the Young Academic Leaders Project of Zhejiang Province (PD2013170). 


\section{References}

[1] H.J. Hamlin, B.C. Moore, T.M. Edwards, I.L.V. Larkin, A. Boggs, W.J. High, K.L. Main, L.J. Guillette Jr, Nitrate-induced elevations in circulating sex steroid concentrations in female Siberian sturgeon (Acipenser baeri) in commercial aquaculture, Aquaculture 281 (2008) 118.

[2] G.D. Agrawal, S.K. Lunkad, T. Malkhed, Diffuse agricultural nitrate pollution of groundwaters in India, Water Sci. Technol. 39 (1999) 67.

[3] A.R. Townsend, R.W. Howarth, F.A. Bazzaz, M.S. Booth, C.C. Cleveland, S.K. Collinge, A.P. Dobson, P.R. Epstein, E.A. Holland, D.R. Keeney, M.A. Mallin, C.A. Rogers, P. Wayne, A.H. Wolfe, Human health effects of a changing global nitrogen cycle, Front. Ecol. Environ. 1 (2003) 240.

[4] T. Khin, A.P. Annachhatre, Novel microbial nitrogen removal processes, Biotechnol. Adv. 22 (2004) 519.

[5] G. Zhan, L. Zhang, D. Li, W. Su, Y. Tao, J. Qian, Autotrophic nitrogen removal from ammonium at low applied voltage in a single-compartment microbial electrolysis cell, Bioresour. Technol. 116 (2012) 271.

[6] M. Zhou, W. Fu, H. Gu, L. Lei, Nitrate removal from groundwater by a novel three-dimensional electrode biofilm reactor, Electrochim. Acta 52 (2007) 6052.

[7] Y. Cong, Q. Xu, H. Feng, D. Shen, Efficient electrochemically active biofilm denitrification and bacteria consortium analysis, Bioresour. Technol. 132 (2013) 24.

[8] W.T. Mook, M.K.T. Aroua, M.H. Chakrabarti, I.M. Noor, M.F Irfan, C.T.J. Low, A 
review on the effect of bio-electrodes on denitrification and organic matter removal processes in bio-electrochemical systems, J. Ind. Eng. Chem. 19 (2013) 1.

[9] D. Wan, H. Liu, J. Qu, P. Lei, Bio-electrochemical denitrification by a novel proton-exchange membrane electrodialysis system-a batch mode study, J. Chem. Technol. Biot. 85 (2010) 1540.

[10]K. Doudrick, T. Yang, K. Hristovski, P. Westerhoff, Photocatalytic nitrate reduction in water: Managing the hole scavenger and reaction by-product selectivity, Appl. Catal. B-Environ. 136 (2013) 40.

[11] J. Nemoto, N. Gokan, H. Ueno, M. Kaneko, Photodecomposition of ammonia to dinitrogen and dihydrogen on platinized $\mathrm{TiO}_{2}$ nanoparticules in an aqueous solution, J. Photoch. Photobio. A 185 (2007) 295.

[12]T. Yang, K. Doudrick, P. Westerhoff, Photocatalytic reduction of nitrate using titanium dioxide for regeneration of ion exchange brine, Water Res. 47 (2013) 1299.

[13]H. Wang, X. Zhang, Y. Su, H. Yu, S. Chen, X. Quan, F. Yang, Photoelectrocatalytic oxidation of aqueous ammonia using $\mathrm{TiO}_{2}$ nanotube arrays, Appl. Surf. Sci. 311 (2014) 851.

[14]N. Wehbe, M. Jaafar, C. Guillard, J.M. Herrmann, S. Miachon, E. Puzenat, N. Guilhaume, Comparative study of photocatalytic and non-photocatalytic reduction of nitrates in water, Appl. Catal. A-Gen. 368 (2009) 1.

[15]L. Li, Z. Xu, F. Liu, Y. Shao, J. Wang, H. Wan, S. Zheng, Photocatalytic nitrate 
reduction over $\mathrm{Pt}-\mathrm{Cu} / \mathrm{TiO}_{2}$ catalysts with benzene as hole scavenger, J. Photoch. Photobio. A. 212 (2009) 113.

[16]J. Sá, C.A. Agüera, S. Gross, J.A. Anderson, Photocatalytic nitrate reduction over metal modified $\mathrm{TiO}_{2}$, Appl. Catal. B-Environ. 85 (2009) 192.

[17]C. Hu, X. Hu, L. Wang, J. Qu, A. Wang, Visible-light-induced photocatalytic degradation of azo dyes in aqueous $\mathrm{AgI} / \mathrm{TiO}_{2}$ dispersion, Environ. Sci. Technol. 40 (2006) 7903.

[18]D. Wu, M. Long, Realizing visible-light-induced self-cleaning property of cotton through coating $\mathrm{N}-\mathrm{TiO}_{2}$ film and loading AgI particles, Appl. Mater. Interfaces 3 (2011) 4770.

[19]Y. Li, H. Zhang, Z. Guo, J. Han, X. Zhao, Q. Zhao, S.J. Kim, Highly efficient visible-light-induced photocatalytic activity of nanostructured $\mathrm{AgI} / \mathrm{TiO}_{2}$ photocatalyst, Langmuir 24 (2008) 8351.

[20]C. Hu, T. Peng, X. Hu, Y. Nie, X. Zhou, J. Qu, H. He, Plasmon-induced photodegradation of toxic pollutants with $\mathrm{Ag}-\mathrm{AgI} / \mathrm{Al}_{2} \mathrm{O}_{3}$ under visible-light irradiation, J. Am. Chem. Soc. 132 (2010) 857.

[21]W. Jiang, C. An, J. Liu, S. Wang, L. Zhao, W. Guo, J. Liu, Facile aqueous synthesis of $\beta$-AgI nanoplates as efficient visible-light-responsive photocatalyst, Dalton Trans. 43 (2014) 300.

[22]H. Wang, Y. Su, H. Zhao, H. Yu, S. Chen, Y. Zhang, X. Quan, Photocatalytic oxidation of aqueous ammonia using atomic single layer graphitic- $\mathrm{C}_{3} \mathrm{~N}_{4}$, Environ. Sci. Technol. 48 (2014) 11984.

[23]K. Doudrick, O. Monzón, A. Mangonon, K. Hristovski, P. Westerhoff, Nitrate 
Reduction in Water Using Commercial Titanium Dioxide Photocatalysts (P25, P90, and Hombikat UV100), J. Environ. Eng-ASCE. 138 (2012) 852.

[24]F. Zhang, R. Jin, J. Chen, C. Shao, W. Gao, L. Li, N. Guan, High photocatalytic activity and selectivity for nitrogen in nitrate reduction on $\mathrm{Ag} / \mathrm{TiO}_{2}$ catalyst with fine silver clusters, J. Catal. 232 (2005) 424.

[25] Y. Chen, L. Hong, H. Xue, W. Han, L. Wang, X. Sun, J. Li, Preparation and characterization of $\mathrm{TiO}_{2}-\mathrm{NTs} / \mathrm{SnO}_{2}-\mathrm{Sb}$ electrodes by electrodeposition, J. Electroanal. Chem. 648 (2010) 119.

[26]M. Prosnansky, Y. Sakakibarab, M. Kuroda, High-rate denitrification and SS rejection by biofilm-electrode reactor (BER) combined with microfiltration, Water Res. 36 (2002) 4801.

[27]APHA, Standard Methods for the Examination of Water and Wastewaters, $20^{\text {th }}$ ed, American Public Health Association, Washington, DC. 1998.

[28]J.R.V. Flora, M.T. Suidan, S. Islam, P. Biswas, Y. Sakakibara, Numerical modeling of a biofilm-electrode reactor used for enhanced denitrification, Water Sci. Technol. 29 (1994) 517.

[29] J.H. Shin, B.I. Sang, Y.C. Chung, Y.k. Choung, The removal of nitrogen using an autotrophic hybrid hollow-fiber membrane biofilm reactor, Desalination 183 (2006) 447.

[30]M. Kurt, I.J. Dunn, J.R. Bourne, Biological denitrification of drinking water using autotrophic organisms with $\mathrm{H}_{2}$ in a fluidized-bed biofilm reactor, Biotechnol. Bioeng. 29 (1987) 493. 
[31] S.E. Oh, K.S. Kim, H.C. Choi, J. Cho, I.S. Kim, Kinetics and physiological characteristics of autotrophic dentrification by denitrifying sulfur bacteria, Water Sci. Technol. 42 (2000) 59.

[32] A. Klapwuk, J. Drent, J.H.A.M. Steenvoorden, A modified procedure for the TTC-dehydrogenase test in activated-sludge, Water Res. 8 (1974) 121.

[33] M.D. Ward, J.R. White, A.J. Bard, Electrochemical investigation of the energetics of particulate titanium dioxide photocatalysts. The methyl viologen-acetate system, J. Am. Chem. Soc., 105 (1983) 27. 


\section{Figure Captions}

Fig. 1. A schematic diagram and the basic principle of the reactor.

Fig. 2. $\mathrm{NH}_{4}{ }^{+}-\mathrm{N}$ removal (a), $\mathrm{NO}_{3}{ }^{-}-\mathrm{N}$ and $\mathrm{NO}_{2}{ }^{-}-\mathrm{N}$ formation (b) with and without visible light irradiation; Mass balances during $\mathrm{NH}_{4}{ }^{+}-\mathrm{N}$ removal by photocatalytic oxidation (c). Reaction conditions: applied voltage $=3.0 \mathrm{~V}(2.71$ $\left.\mathrm{mA} / \mathrm{cm}^{2}\right), \mathrm{pH} 8.0$, Initial $\mathrm{NH}_{4}{ }^{+}-\mathrm{N}=35.0 \mathrm{mg} / \mathrm{L}$.

Fig. 3. Concentration variations of $\mathrm{NH}_{4}{ }^{+}-\mathrm{N}$ (a), $\mathrm{NO}_{3}{ }^{-}-\mathrm{N}$ (b), $\mathrm{NO}_{2}{ }^{-}-\mathrm{N}$ (c) using $\mathrm{AgI} / \mathrm{TiO}_{2}-\mathrm{NTs}$ anode and an autotrophic denitrifying biofilms cathode or a graphite cathode under visible light irradiation. Reaction conditions: applied voltage $=3.0 \mathrm{~V}\left(2.71 \mathrm{~mA} / \mathrm{cm}^{2}\right), \mathrm{pH} 8.0$, Initial $\mathrm{NH}_{4}{ }^{+}-\mathrm{N}=35.0 \mathrm{mg} / \mathrm{L}$, Initial $\mathrm{NO}_{3}{ }^{-} \mathrm{N}=20.0 \mathrm{mg} / \mathrm{L}$.

Fig. 4. Effects of different applied voltages $(0,1.0,2.0,3.0$ and $4.0 \mathrm{~V})$ on $\mathrm{NH}_{4}{ }^{+}-\mathrm{N}$ removal (a) $\mathrm{NO}_{3}{ }^{-} \mathrm{N}$ removal and $\mathrm{NO}_{2}{ }^{-} \mathrm{N}$ formation (b), TN removal (c) in the reactor at $\mathrm{pH}$ value of 8.0. Reaction conditions: Initial $\mathrm{NH}_{4}{ }^{+}-\mathrm{N}=35.0 \mathrm{mg} / \mathrm{L}$, Initial $\mathrm{NO}_{3}{ }^{-} \mathrm{N}=20.0 \mathrm{mg} / \mathrm{L}$. The current densities at different applied potentials (from $1.0 \mathrm{~V}$ to $4.0 \mathrm{~V}$ ) were $0.29 \mathrm{~mA} / \mathrm{cm}^{2}(1.0 \mathrm{~V}), 1.73 \mathrm{~mA} / \mathrm{cm}^{2}(2.0 \mathrm{~V}), 2.71$ $\mathrm{mA} / \mathrm{cm}^{2}(3.0 \mathrm{~V})$ and $3.8 \mathrm{~mA} / \mathrm{cm}^{2}(4.0 \mathrm{~V})$, respectively.

Fig. 5. Effects of different $\mathrm{pH}\left(6.0,7.0,7.5,8.0\right.$ and 9.0) on $\mathrm{NO}_{3}{ }^{-} \mathrm{N}$ removal (a), $\mathrm{NH}_{4}{ }^{+}-\mathrm{N}$ removal (b), TN removal (c) in the reactor. Reaction conditions: applied voltage $=3.0 \mathrm{~V}\left(2.71 \mathrm{~mA} / \mathrm{cm}^{2}\right)$, Initial $\mathrm{NH}_{4}{ }^{+}-\mathrm{N}=35.0 \mathrm{mg} / \mathrm{L}$, Initial $\mathrm{NO}_{3}{ }^{-} \mathrm{N}=20.0 \mathrm{mg} / \mathrm{L}$.

Fig. 6. Cyclic removal of $\mathrm{NH}_{4}{ }^{+}-\mathrm{N}$ using $\mathrm{AgI} / \mathrm{TiO}{ }_{2}-\mathrm{NTs}$ anode and an autotrophic denitrifying biofilm cathode under visible light irradiation at optimized condition (a), and cyclic photocurrent response of $\mathrm{AgI} / \mathrm{TiO}_{2}-\mathrm{NT}$ anode $0.1 \mathrm{M}$ $\mathrm{Na}_{2} \mathrm{SO}_{4}$ solution (b).

Fig. 7. Effect of visible light irradiation on dehydrogenase activity of the biofilm cathode at applied potential of $3.0 \mathrm{~V}\left(2.71 \mathrm{~mA} / \mathrm{cm}^{2}\right)$.

Fig. 8. The probable nitrogen removal pathways in the process (a); Bandgap structure of $\mathrm{AgI} / \mathrm{TiO}_{2}-\mathrm{NTs}$ and the solution redox positions for $\mathrm{NH}_{4}{ }^{+}$oxidation (b). 


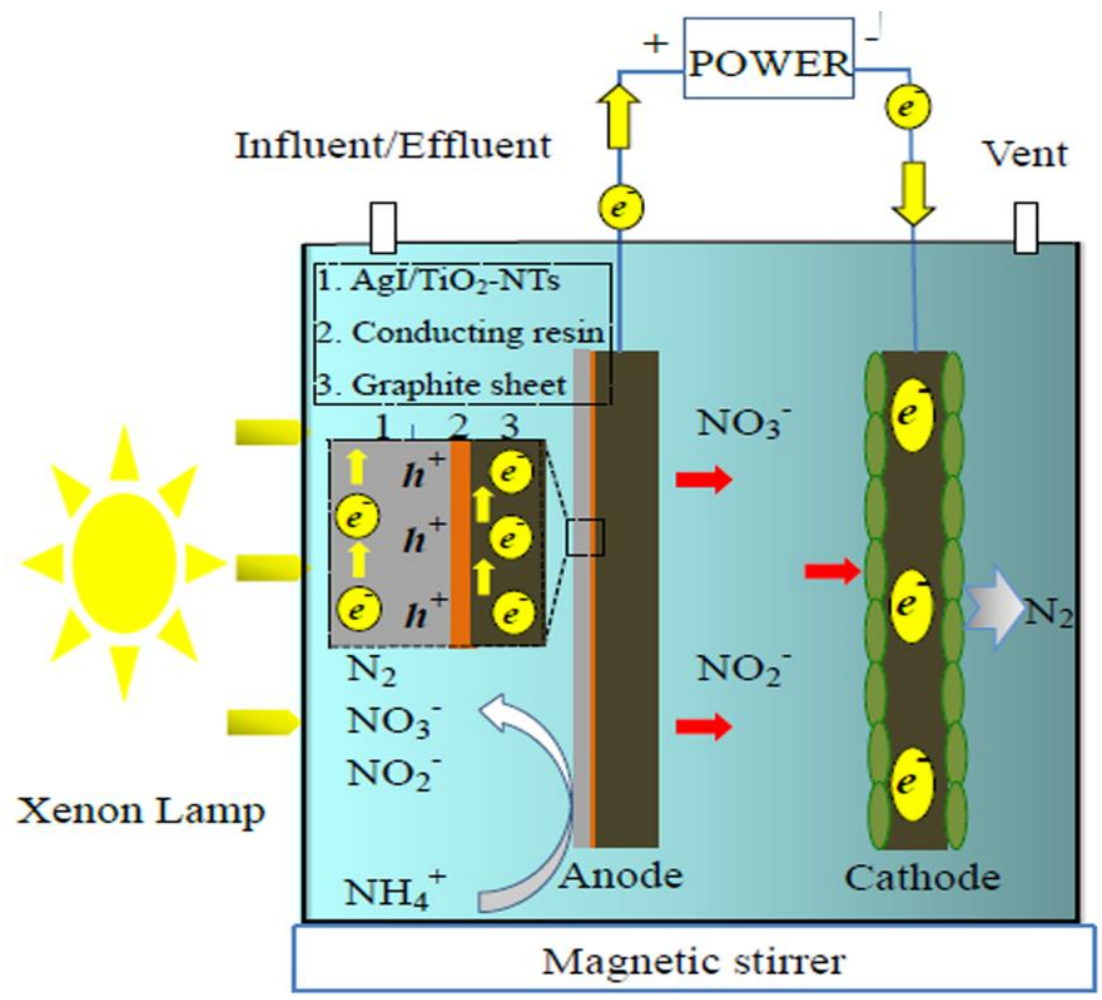

Fig. 1. A schematic diagram and the basic principle of the reactor. 

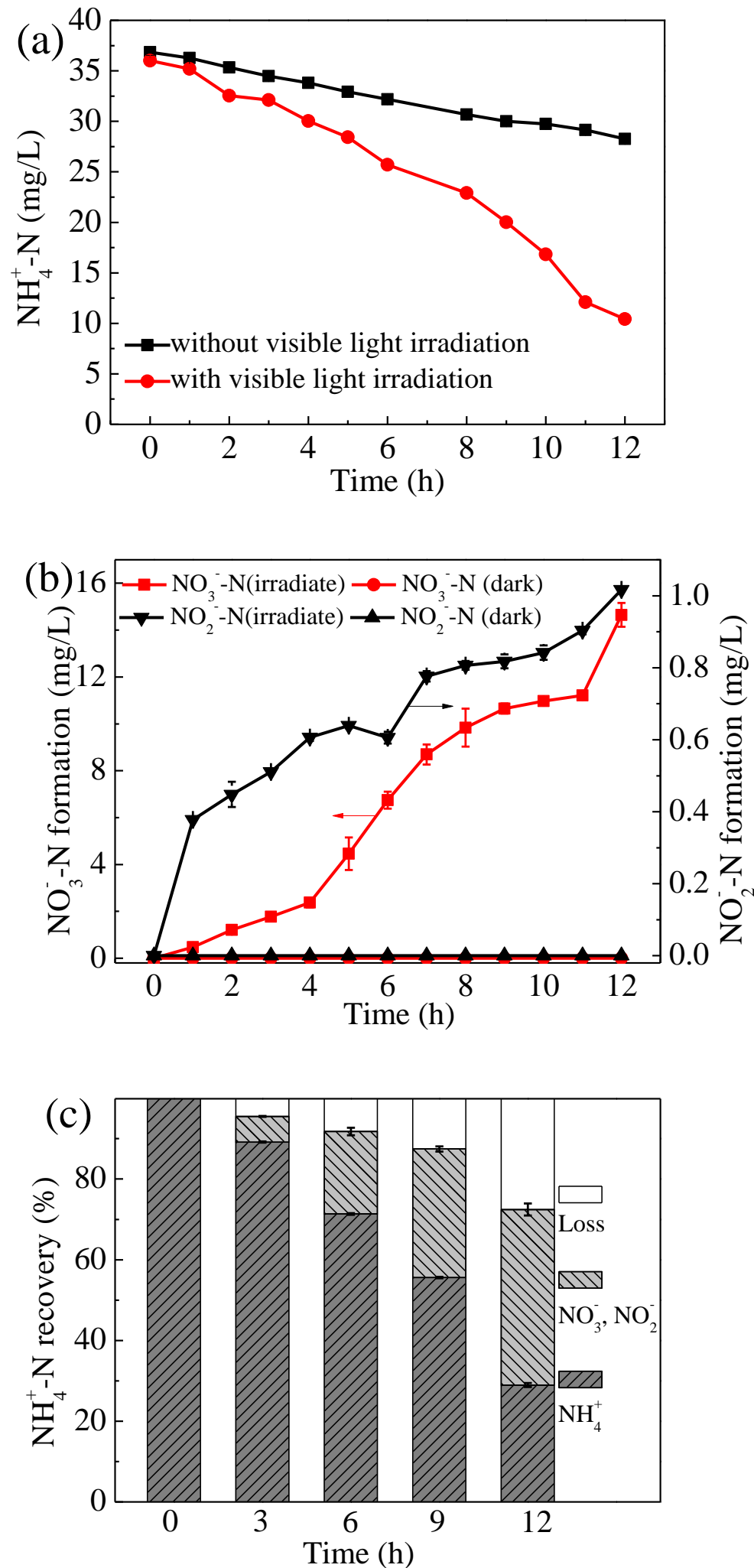

Fig. 2. $\mathrm{NH}_{4}{ }^{+}-\mathrm{N}$ removal (a), $\mathrm{NO}_{3}{ }^{-}-\mathrm{N}$ and $\mathrm{NO}_{2}{ }^{-}-\mathrm{N}$ formation (b) with and without visible light irradiation; Mass balances during $\mathrm{NH}_{4}{ }^{+}-\mathrm{N}$ removal by photocatalytic oxidation (c). Reaction conditions: applied voltage $=3.0 \mathrm{~V}\left(2.71 \mathrm{~mA} / \mathrm{cm}^{2}\right), \mathrm{pH} 8.0$, Initial $\mathrm{NH}_{4}{ }^{+}-\mathrm{N}=35.0 \mathrm{mg} / \mathrm{L}$. 

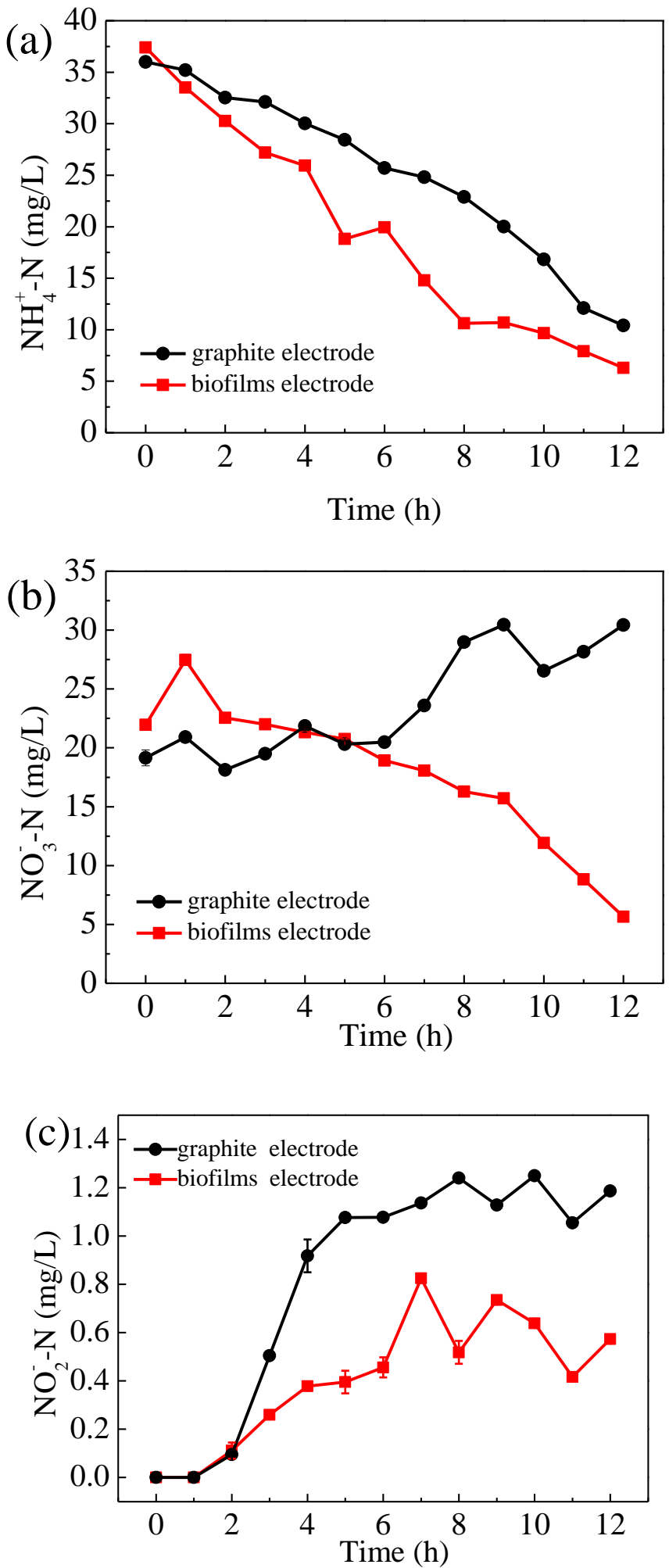

Fig. 3. Concentration variations of $\mathrm{NH}_{4}{ }^{+}-\mathrm{N}$ (a), $\mathrm{NO}_{3}{ }^{-}-\mathrm{N}$ (b), $\mathrm{NO}_{2}{ }^{-}-\mathrm{N}$ (c) using $\mathrm{AgI} / \mathrm{TiO}_{2}-\mathrm{NTs}$ anode and an autotrophic denitrifying biofilm cathode or a graphite cathode under visible light irradiation. Reaction conditions: applied voltage $=3.0 \mathrm{~V}$ $\left(2.71 \mathrm{~mA} / \mathrm{cm}^{2}\right), \mathrm{pH} 8.0$, Initial $\mathrm{NH}_{4}{ }^{+}-\mathrm{N}=35.0 \mathrm{mg} / \mathrm{L}$, Initial $\mathrm{NO}_{3}{ }^{-} \mathrm{N}=20.0 \mathrm{mg} / \mathrm{L}$. 

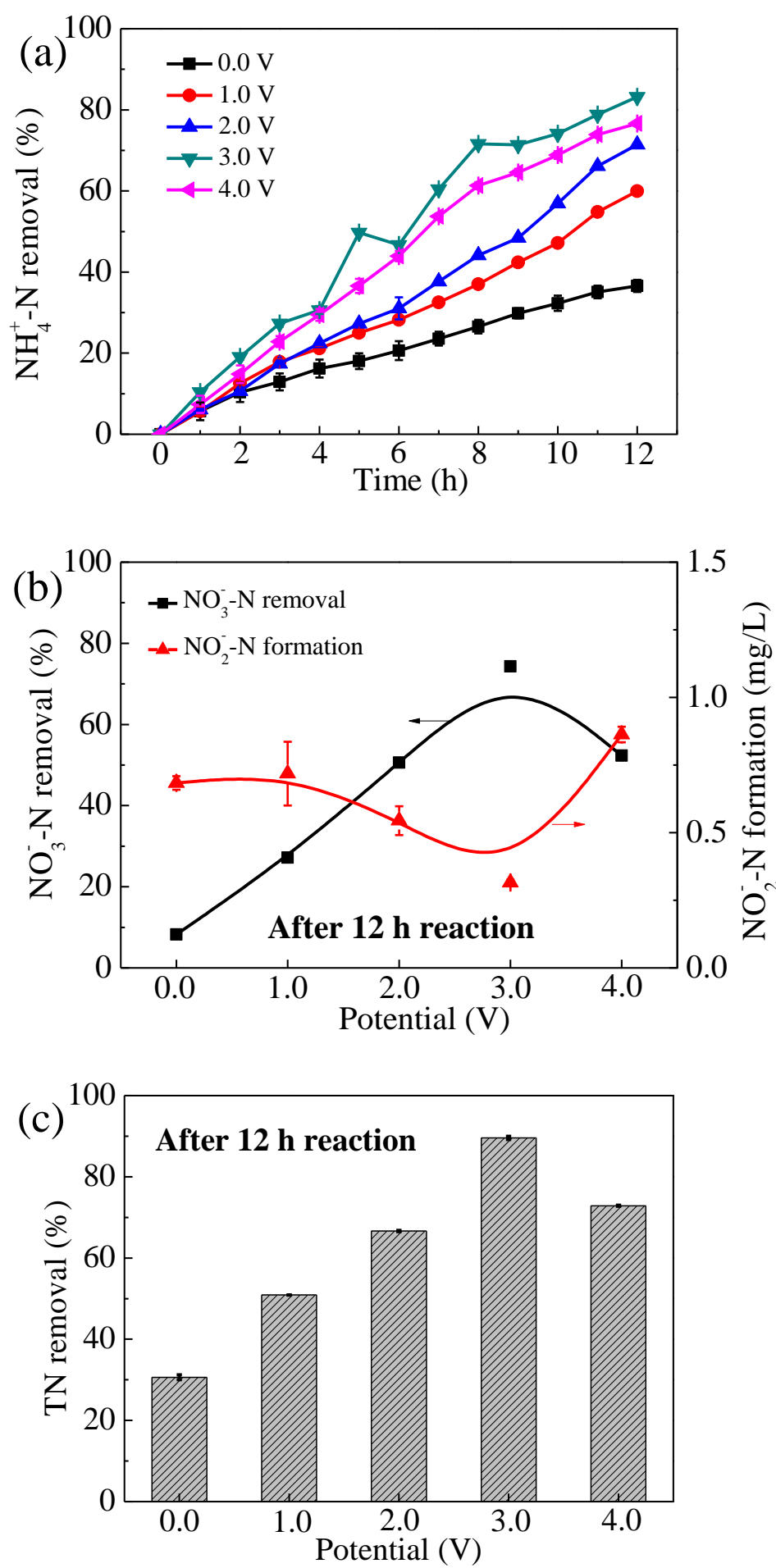

Fig. 4. Effects of different applied voltages $(0,1.0,2.0,3.0$ and $4.0 \mathrm{~V})$ on $\mathrm{NH}_{4}{ }^{+}-\mathrm{N}$ removal (a), $\mathrm{NO}_{3}{ }^{-}-\mathrm{N}$ removal and $\mathrm{NO}_{2}{ }^{-} \mathrm{N}$ formation (b), $\mathrm{TN}$ removal (c) in the reactor at $\mathrm{pH}$ value of 8.0. Reaction conditions: Initial $\mathrm{NH}_{4}{ }^{+}-\mathrm{N}=35.0 \mathrm{mg} / \mathrm{L}$, Initial $\mathrm{NO}_{3}{ }^{-} \mathrm{N}=$ $20.0 \mathrm{mg} / \mathrm{L}$. The current densities at different applied potentials (from $1.0 \mathrm{~V}$ to $4.0 \mathrm{~V}$ ) were $0.29 \mathrm{~mA} / \mathrm{cm}^{2}(1.0 \mathrm{~V}), 1.73 \mathrm{~mA} / \mathrm{cm}^{2}(2.0 \mathrm{~V}), 2.71 \mathrm{~mA} / \mathrm{cm}^{2}(3.0 \mathrm{~V})$ and 3.8 $\mathrm{mA} / \mathrm{cm}^{2}(4.0 \mathrm{~V})$, respectively. 

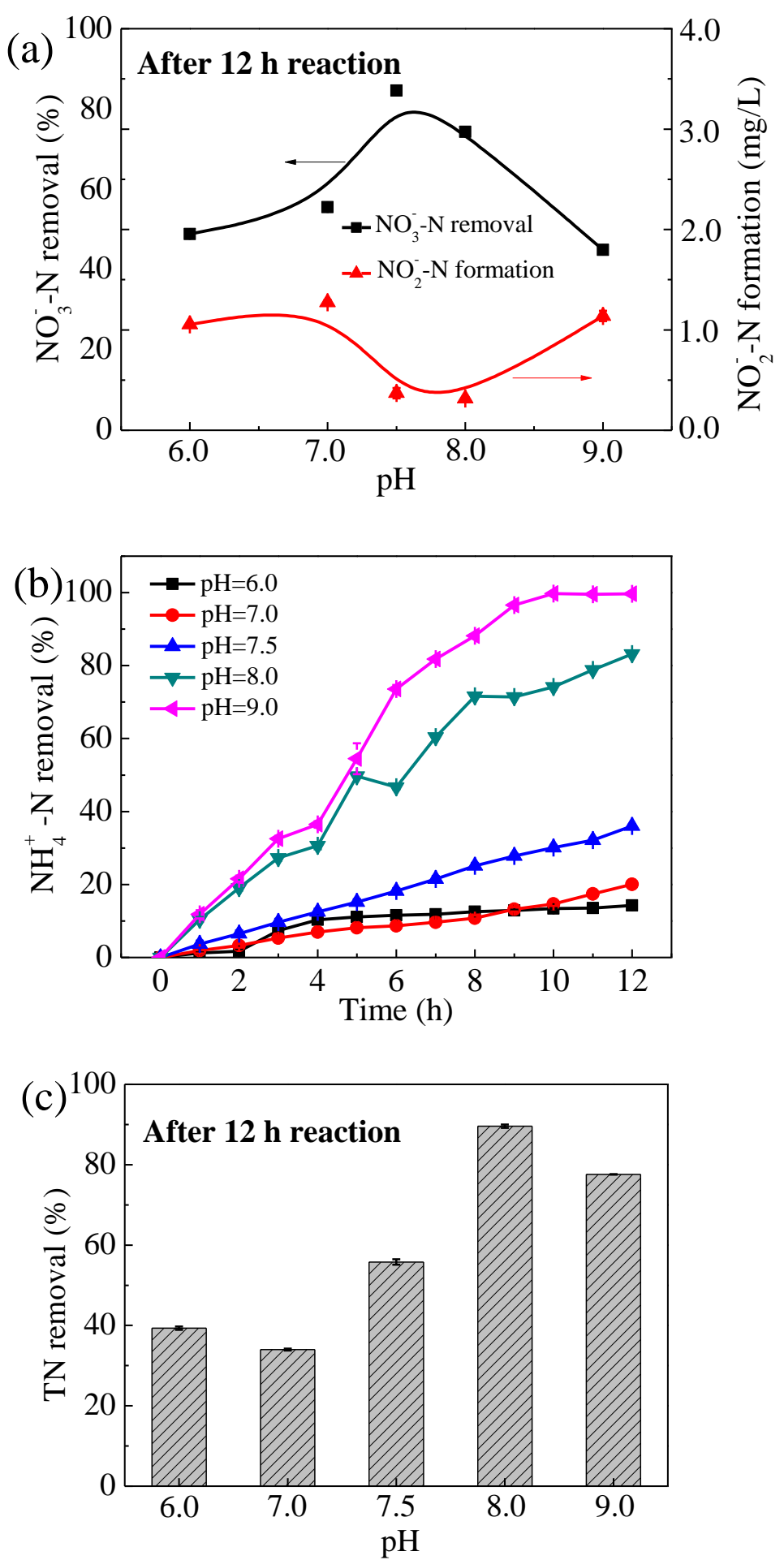

Fig. 5. Effects of different $\mathrm{pH}\left(6.0,7.0,7.5,8.0\right.$ and 9.0) on $\mathrm{NO}_{3}{ }^{-} \mathrm{N}$ removal (a), $\mathrm{NH}_{4}{ }^{+}-\mathrm{N}$ removal (b), TN removal (c) in the reactor. Reaction conditions: applied voltage $=3.0 \mathrm{~V}\left(2.71 \mathrm{~mA} / \mathrm{cm}^{2}\right)$, Initial $\mathrm{NH}_{4}{ }^{+}-\mathrm{N}=35.0 \mathrm{mg} / \mathrm{L}$, Initial $\mathrm{NO}_{3}{ }^{-}-\mathrm{N}=20.0$ $\mathrm{mg} / \mathrm{L}$. 

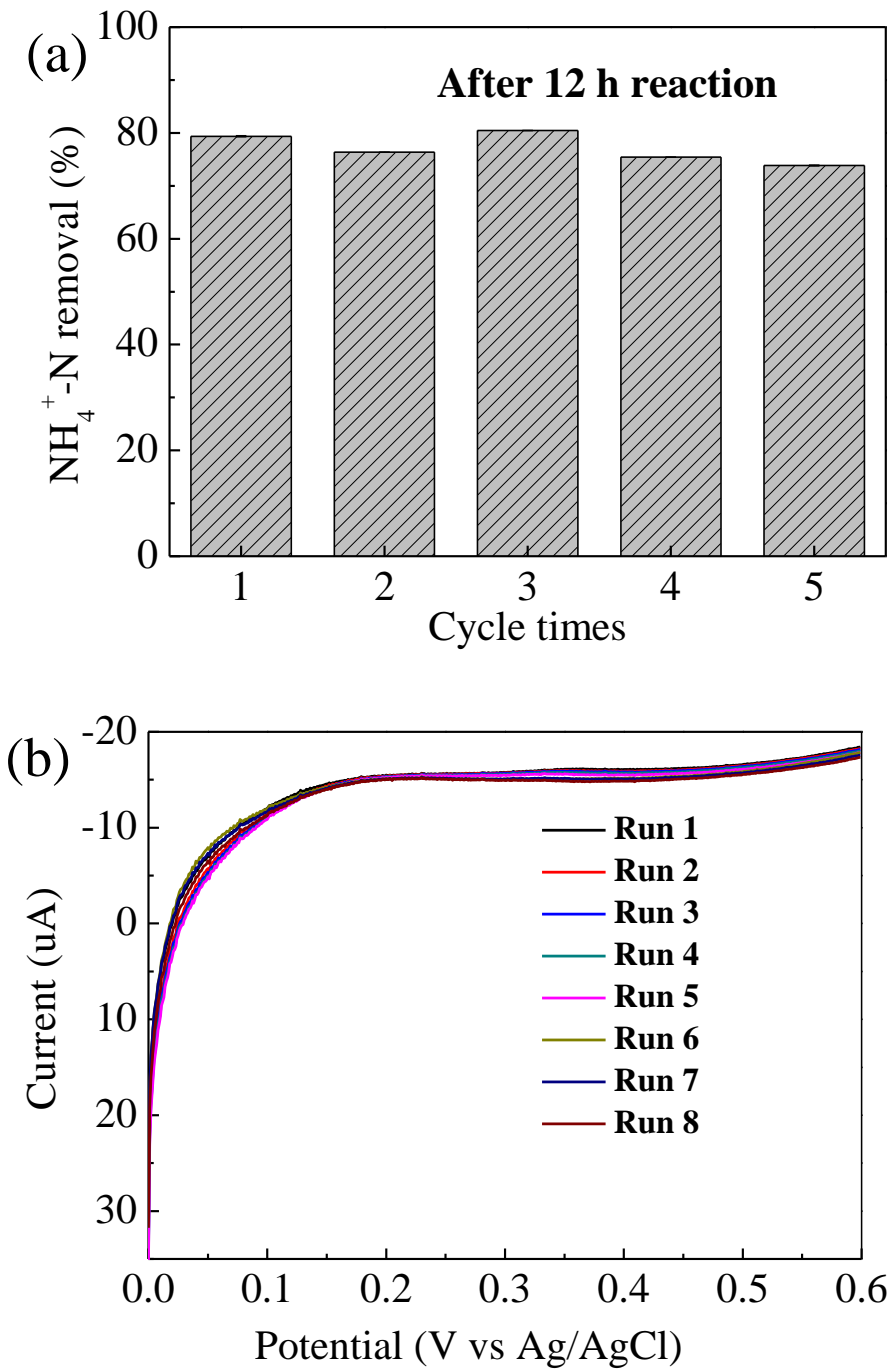

Fig. 6. Cyclic removal of $\mathrm{NH}_{4}{ }^{+}-\mathrm{N}$ using $\mathrm{AgI} / \mathrm{TiO}{ }_{2}-\mathrm{NTs}$ anode and an autotrophic denitrifying biofilm cathode under visible light irradiation at optimized condition (a); cyclic photocurrent response of $\mathrm{AgI} / \mathrm{TiO}_{2}-\mathrm{NTs}$ anode in $0.1 \mathrm{M} \mathrm{Na}_{2} \mathrm{SO}_{4}$ solution (b). 


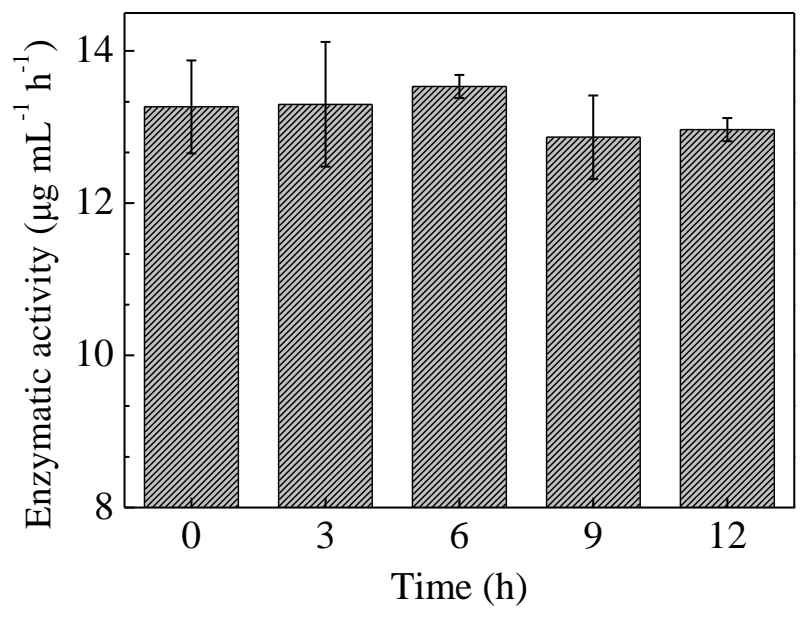

Fig. 7. Effect of visible light irradiation on dehydrogenase activity of the biofilm cathode at applied potential of $3.0 \mathrm{~V}\left(2.71 \mathrm{~mA} / \mathrm{cm}^{2}\right)$. 

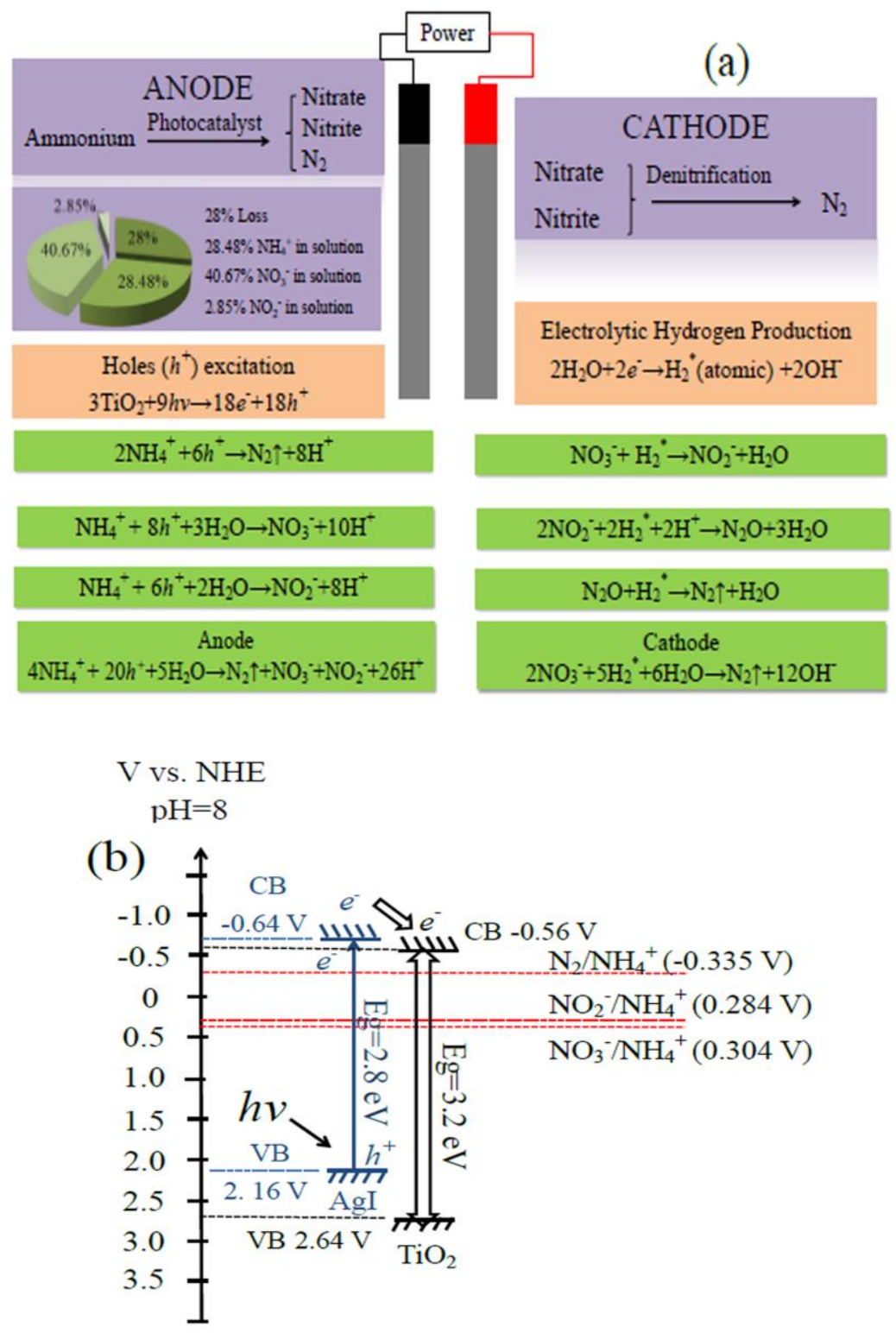

Fig. 8. The probable nitrogen removal pathways in the process (a); Bandgap structure of $\mathrm{AgI} / \mathrm{TiO}_{2}-\mathrm{NTs}$ and the solution redox positions for $\mathrm{NH}_{4}{ }^{+}$oxidation (b). 


\section{Graphical Abstract}

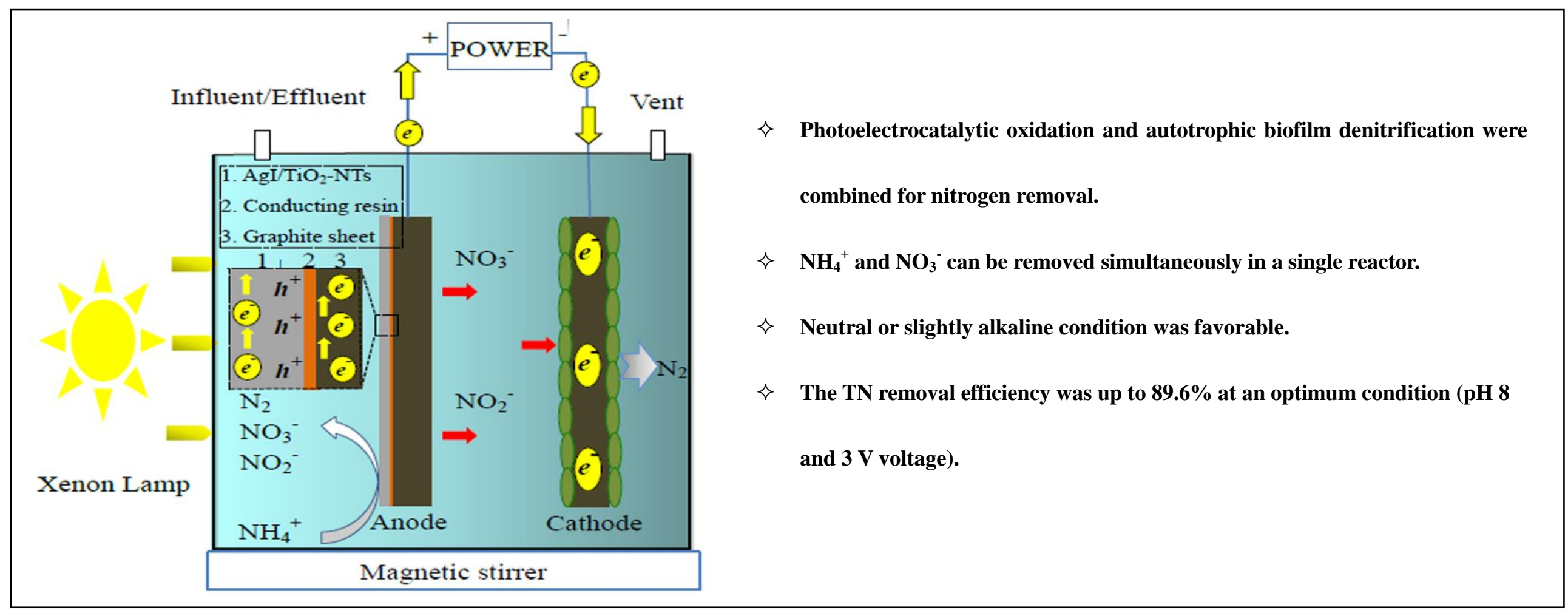

